\title{
Towards Dual Nationality: China's Legal and Policy Initiative for Human and Capital Inflow and Promotion of Social Justice*
}

Yin $\mathrm{Liu}^{* *}$

China's sole nationality principle was formulated at the beginning of the People's Republic of China. However, it was not officially adopted as a legal standard until 1980 when New China promulgated its first nationality act. Sole nationality, initiated as an expedient for foreign policy, was originally designed to help with neighbourliness. However, not only did it fail to achieve this goal, but it even resulted in more domestic institutional discrimination among Chinese people. Nowadays, in such a globalization and 'humanrightization' era, international law and domestic nationality laws in most countries throughout the world recognize an individual's right to a nationality, and accept dual nationality so as to facilitate migrants' returning to their homelands and help them reintegrate into local communities. Contemporary theory and practice of international law support the legitimacy of dual nationality. Also, China has experience in dealing with dual nationality. It would therefore be legitimate, beneficial and practical for China to restore dual nationality.

* The term 'nationality' used in this article, limited to its narrowest sense, refers only to the nationality of human beings, excluding those of artificial persons, vessels and aircrafts. This article uses 'nationality', a term of international law, instead of 'citizenship,' denoting an individual's relationship with a sovereign state, not with a jurisdiction or legal unit.

** Associate Professor of International Law at Huaqiao University (HQU), China; Research Fellow of HQU Institute of Overseas Chinese Legal Affairs, and of HQU Institute of East Asian Legal Culture. B.A. (South Central China Univ. of Political Science and Law), LL.M. (Zhongnan Univ. of Economics and Law), Ph.D. (Wuhan). My appreciation goes to Dr. Jonathan Harrington (Professor at Troy University, US) and Dr. Eric Y. J. Lee for their warm encouragements and help. The author may be contacted at: carollew@hotmail.com/Address: Faculty of Law, Huaqiao University, Chenghua North Road 269\# Quanzhou, Fujian 362021 P. R. China. 
Keywords: Sole Nationality, Right to Nationality, Expatriation, Prohibition of Arbitrary Deprivation of Nationality, Dual Nationality

'Nationality has no positive, immutable meaning.' -Harvard Research in International Law (1929)-

\section{INTRODUCTION}

The People's Republic of China ("PRC")'s 's dual nationality campaign started around two decades ago ${ }^{3}$ in response to the serious challenges of the out-migration 'brain drain' and capital outflow. ${ }^{4}$ But the government repeatedly rejected requests for dual nationality. ${ }^{5}$ Instead, it granted foreigners permanent residency to attract foreign talent, intended as a strategy to relieve China from reverse brain drain and capital outflow. However, it caused more new problems than it solved.

Continuing outflows of talent and capital combined with unsuccessful foreigner permanent residency policies are made worse by China's sole nationality policy. The Chinese government has been pressed to restore the dual nationality system, which was accepted long before by most countries throughout the world, but to no avail.

The primary purpose of this research is to analyse legal and policy questions regarding China's nationality principle by reviewing the historical evolution of China's nationality law. The author will further redefine the concept of 'nationality' from both domestic and international legal perspectives. This paper is composed of six parts including a short Introduction and Conclusion. Parts two and three will review the sole nationality policy in China from a critical perspective. The author concludes that this policy has led to irreversible outflows of talent and capital, and even discrimination among Chinese population groups. ${ }^{6}$ Part four will introduce dual nationality as it exists in international law as a means for the humanrightization $^{7}$ of international law. Part five will examine dual nationality practice in China. 


\section{Formulation of China Nationality LaW}

It was not until the 1950s that the sole nationality policy was adopted in China. Once in office, the Chinese Communist Party ("CCP") was immediately concerned about overseas Chinese and their questionable allegiance to New China. ${ }^{8}$ Dual nationality among those Chinese was seen as a liability to the PRC when it was seeking to establish diplomatic relations. China voluntarily showed its willingness to settle that question ${ }^{9}$ so as to avoid inter-state conflicts, especially with Southeast Asian countries. ${ }^{10}$

Beginning in $1955,{ }^{11}$ China suddenly changed its nationality policy during the Afro-Asia Conference in Bandung. On April 22, 1955, China signed the Agreement on the Issue of Dual Nationality between the Republic of Indonesia and the People's Republic of China ${ }^{12}$ (hereinafter 1955 Sino-Indonesian Agreement) in Bandung, which denied the nationals of either party the right to have the nationality of the other (Articles 1-7). ${ }^{13}$ Those provisions might be viewed as a starting point for China's sole nationality principle. Since then, China has clung to it. In the following decades, those provisions were subsequently written into China's dual nationality agreements with its other neighbouring countries including Malaysia (1974), ${ }^{14}$ the Philippines (1975), ${ }^{15}$ and Thailand (1975). ${ }^{16}$

In 1980, the PRC enacted the Nationality Act of the People's Republic of China (hereinafter 1980 Nationality $\mathrm{Act}^{17}$ ), even more rigid on dual nationality than any other domestic legal document or bilateral agreement before. ${ }^{18}$ The purpose of the 1980 Nationality Act, according to Sheng $\mathrm{Yu}^{19}$ and Wang Keju ${ }^{20}$ at the Chinese Academy of Social Sciences ("CASS"), was to reassure Asian countries with sizable Chinese minorities that China did not intend to use the issue of nationality to interfere with their domestic affairs. ${ }^{21}$ Table 1 shows the key provisions of the 1980 Nationality Act. 
Table 1: The 1980 National Act of PRC

\begin{tabular}{c|l}
\hline Articles & \multicolumn{1}{c}{ Regulations } \\
\hline Article 3 & The PRC does not recognize dual nationality for any Chinese national. \\
\hline Article 5 & $\begin{array}{l}\text { A person whose parents are both Chinese nationals and have both settled } \\
\text { abroad, or one of whose parents is a Chinese national and has settled abroad, } \\
\text { and who has acquired foreign nationality at birth shall not have Chinese } \\
\text { nationality. }\end{array}$ \\
\hline Article 8 & $\begin{array}{l}\text { Any person who applies for naturalization as a Chinese national shall } \\
\text { acquire Chinese nationality upon approval of his application; a person whose } \\
\text { application for naturalization as a Chinese national has been approved shall } \\
\text { not retain foreign nationality. }\end{array}$ \\
\hline Article 9 & $\begin{array}{l}\text { Any Chinese national who has settled abroad and who has been naturalized } \\
\text { as a foreign national or has acquired foreign nationality of his own free will } \\
\text { shall automatically lose Chinese nationality. }\end{array}$ \\
\hline Article 13 & $\begin{array}{l}\text { Foreign nationals who once held Chinese nationality may apply for } \\
\text { restoration of Chinese nationality if they have legitimate reasons; those } \\
\text { whose applications for restoration of Chinese nationality have been approved } \\
\text { shall not retain foreign nationality. }\end{array}$ \\
\hline
\end{tabular}

In practice, if a Chinese national has established a permanent home abroad without naturalization, $\mathrm{s} / \mathrm{he}$ is required to have her/his household registration together with the identification card deregistered. ${ }^{22}$

\section{Problems with Sole Nationality in China}

\section{A. Sole Nationality Does Not Promote Neighbourliness}

The 1955 Sino-Indonesia Agreement did not stop the Indonesian anti-Chinese riots that followed in later years. ${ }^{23}$ After Haji Mohammad Suharto came to power, Indonesia unilaterally renounced the agreement in 1966 and even broke off its diplomatic relations with Beijing. Those riots were triggered by either anticommunism or resentment against rich people, most of whom were Chinese minorities. ${ }^{24}$ Dual nationality itself was not the point at issue. As Peter J. Spiro says, the ultimate threat inherent in dual nationality does not lie a situation 
whereby "citizens are not (enough) loyal to his/her country," but the confrontation between countries it may lead to. ${ }^{25}$

\section{B. Discriminatory Expatriation \& Allegiance Conflict}

Article 9 of the 1980 Nationality Act provides for forced expatriation upon naturalization, possibly leading to an arbitrary deprivation of nationality. However, Article 12 explicitly denies public employees and servicemen the right to expatriate rather than revoking their Chinese nationality upon naturalization. It implies that those functionaries may have dual nationality, which is generally prohibited by the nationality laws of many other countries because of loyalty conflicts arising therefrom.

\section{Discrimination against Local Chinese}

China is now experiencing its third international migration wave. ${ }^{26}$ The current one is unique not only because most of the migrants are hi-tech talents and business elites, but also because many of these migrants, though naturalized abroad with their families, still keep working in China. ${ }^{27}$ Thanks to the super-national treatment, foreigners keep pre-empting local resources, appropriating local citizens' living space, exploiting the local market while exchanging CNY into foreign currencies and transferring wealth abroad. The sole nationality principle facilitates their raking in profits from the Chinese market on more favoured terms and conditions, ${ }^{28}$ essentially discriminating against local Chinese citizens. Were this to continue, China might in fact soon turn into an economic colony of those powerful Chinese dual nationals.

\section{Impaired Social Justice}

Since Pasquale Stanislao Mancini addressed Nationality as the Foundation of THE LAW OF NATIONS (1851), ${ }^{29}$ nationality has always been a major connecting factor of personal jurisdiction, i.e., an important way to extend the territorial scope of domestic law. If China supports absolute sole nationality, e.g., it waives its personal jurisdiction over its nationals living abroad. Its negative effects are found particularly in investment arbitrations. Siag \& Vecchi v. Egypt is a good example. As the ICSID emphasized in this case, the question of effective nationality requires in the first place that the claimants possess dual nationality as a matter of law. ${ }^{31}$ 
Otherwise, no conflict of nationality existed as we found in Siag v. Egypt. ${ }^{32}$

Truly, the sole nationality principle helps prevent the conflict of nationality, but narrows down judicial discretion, leading to a higher risk of improper jurisdiction as well as improper application of law. The conflict of nationality would be better dealt with by either international law or conflict of laws. ${ }^{33}$ Additionally, sole nationality has a particularly negative impact on China with regard to criminal jurisdiction. There are many corrupt Chinese officials who flee abroad with large amounts of illicit money. The sole nationality principle obviously works against prosecuting those people and crimes.

\section{E. Prohibitive Return \& Unsuccessful Foreigners' Permanent Residency}

At the end of 2003, China promulgated the Administrative Rules for Granting Foreigners' Permanent Residence in China (hereinafter 2003 Rules). Under the 2003 Rules, any foreign individual who applies for permanent residence in China must:

1. hold a senior position or enjoy the same treatment as a senior fellow deserves and 2. be employed by one of those institutions or agencies affiliated to the Chinese National Government or a provincial government, key universities, business enterprises which carry out national major engineering or scientific research projects, public institutes, hi-tech companies, foreign-invested companies engaged in certain industries which foreigners are encouraged to invest in and which apply advanced technologies or are export-oriented. Apart from it, a foreign individual who invests more than $\$ 500,000$ USD in China may apply as well. $^{34}$

Obviously, the 2003 Rules targets successful foreigners in terms of social status and individual wealth. However, few Chinese migrants have been integrated into the upper class in their host countries, in particular, the EU, the US and Japan, ${ }^{35}$ and few returnees would be welcomed at home. Even though these rules were eased in $2015,^{36}$ Chinese permanent residency is still one of the hardest to get in the world, with only an average of 248 green cards issued per year since 2004 . $^{37}$

Due to its unsuccessful permanent residency policy, the Chinese government is under pressure to restore dual nationality, at least conditionally, so as to be more consistent with international norms. ${ }^{38}$ One proposal calls for creating a new 
migrant policy, rather than a new legal rule. It would favour Chinese migrants being naturalized in European and North American countries by allowing them to retain their Chinese nationality, whereas those obtaining naturalization somewhere else could not. ${ }^{39}$ Such a proposal, however, would be neither legitimate nor effective. First, such a policy would not be effective in regulating nationality because it is too flexible and unpredictable. ${ }^{40}$ Second, overseas Chinese ought to be treated equally before the law. Third, contemporary international law has recognized an individual's right to a nationality as a human right. China is obliged to respect international law, which means legally recognizing dual nationality.

\section{Dual Nationality in International Law and China's Stance}

\section{A. Nationality: From Identity to Right}

The concept of nationality was developed in France from the end of the eighteenth century. ${ }^{41}$ Although dual nationality at the time was condemned as worse than bigamy, ${ }^{42}$ the hostility towards different allegiances was never excessive. The 1804 Civil Code of France did not link automatic loss of French nationality with simply possessing another passport. Only an explicit voluntary act in favour of a foreign nationality would end one's attachment to France. ${ }^{43}$

The traditional approach to nationality law can be conceived as a matter of human geography confronted on the same terms as territorial geography. Sovereignty over both space and people were predicates to the maintenance of international order. ${ }^{44}$ International law found an objective in ensuring that all individuals had only one nationality, working against the twin difficulties of statelessness and dual nationality. ${ }^{45}$

As late as 1931, ENCYCLOPEDIA OF THE SOCIAL SCIENCES included 'dual nationality' as essentially an incongruity. ${ }^{46}$ However, neither theory nor practice of international law was sufficient to support the assertion. ${ }^{47}$ It instead remained neutral on dual nationality. ${ }^{48}$

The right to a nationality has been widely accepted as a core human right in contemporary international legal instruments including the Universal Declaration on Human Rights 1948 ("UDHR"), the International Covenant on Civil and 
Political Rights 1966 ("ICCPR"), the American Convention on Human Rights $1969,{ }^{51}$ the Paris Minimum Standards of Human Rights Norms in a State of Emergency $1985,{ }^{52}$ the Arab Charter on Human Rights $1994,{ }^{53}$ the European Convention on Nationality $1997,,^{54}$ and the ASEAN Human Rights Declaration 2012. ${ }^{55}$ The Inter-American Court of Human Rights put it expressively this way: "The classic doctrinal position, which viewed nationality as an attribute granted by the State to its subjects, has gradually evolved to a conception of nationality which, in addition to being the competence of the State, is a human right., ${ }^{, 56}$

In its commentaries to the Draft Articles on the Nationality of Natural Persons in Relation to Succession of States, the International Law Commission highlighted that the evolution of international human rights law has significantly altered the classical doctrine on the preponderance of states' interests over the interests of individuals. ${ }^{57}$ It seems that nationality is becoming more a matter of right or individual choice than one of identity. ${ }^{58}$ Insofar as nationality is so framed, its delimitation can no longer turn on traditional membership criteria, many of which collide with other norms of both liberal democracy and international law. ${ }^{59}$

While the principle of right to a nationality is emerging worldwide, China still views nationality as an identity rather than a right. According to Haopei Li, 'nationality' is an individual's legal identity which shows his/her membership in a given state and which makes him/her subject to that state. ${ }^{60} \mathrm{Li}$ 's definition is the one that Chinese textbooks on international law cite today.

\section{B. Expatriation: From Duty to Right}

Expatriation is linked to the right to change nationality. It was first introduced by the so-called Bancroft Treaties between the US and several German principalities in 1868. It provides that loss of nationality in one party would be recognized upon naturalization in the other. ${ }^{61}$ Between the late nineteenth and the early twentieth centuries, the US sought an international legal requirement that states provide for the possibility of expatriation ${ }^{62}$ but had little success.

Under customary international law, it is up to each state to determine who its nationals are. ${ }^{63}$ This principle was articulated by the Permanent Court of International Justice ("PCIJ") in the Nationality Decrees in Tunis and Morocco case $(1923)^{64}$ and has been codified in both the Convention on Certain Questions relating to the Conflict of Nationality Laws (hereinafter 1930 Hague Convention) 
and the 1997 European Convention on Nationality (hereinafter 1997 European Convention).

An international requirement on states to provide for expatriation posed the prospect of a constraint on nationality determinations. In this regard, the 'right' to expatriation would have constrained states in their municipal determinations of national membership. ${ }^{65}$ Interestingly, a Chinese legal writer clings to that vigorously contested 'norm,' alleging that the right to a nationality means the right to only one nationality. Under this international norm, everyone may have only one nationality, while denying the right to support dual nationality. ${ }^{66}$

That way of thinking completely fails to respect general international law, which has never outlawed dual nationality. Even during the Cold War era ${ }^{67}$ when expatriation was written into quite a few bilateral agreements, including Sinoforeign nationality agreements ${ }^{68}$ and the Convention on the Reduction of Cases of Multiple Nationality and Obligations in Cases of Multiple Nationality (hereinafter 1963 European Convention), the US Supreme Court denied Congress the power to divest an American of his/her citizenship absent voluntary renunciation. ${ }^{69}$ The Court also upheld that the intent to give up one's citizenship must be proved by clear and convincing evidence, ${ }^{70}$ which effectively affirms dual nationality as legitimate. A few years after the Cold War ended, the 1963 European Convention was amended, clearly recognizing a national's right to dual nationality. ${ }^{71}$ Yet in China, residing in a foreign country suffices for automatic loss of Chinese nationality. ${ }^{72}$

\section{Prohibition of Arbitrary Deprivation of Nationality}

The right to retain a nationality is intrinsically linked to the prohibition of arbitrary deprivation of nationality. ${ }^{73}$ Both explicit and implicit prohibition of arbitrarily depriving someone's nationality is regarded as a rule of customary international law. ${ }^{74}$ The International Court of Justice ("ICJ") has defined 'nationality' as a legal bond which has as its basis "a social fact of attachment, a genuine connection of existence, interests and sentiments." ${ }^{, 75}$ It is deemed as not only reflecting a genuine connection but also formalizing the bond of allegiance. ${ }^{76}$ Where such a genuine connection or tie of allegiance is absent, diminished or broken, this can result in the termination of nationality. ${ }^{77}$ Nonetheless, international law requires the state to make such termination legitimately: 
... it [deprivation of nationality] must be in conformity with domestic law and comply with specific procedural and substantive standards, in particular the principle of proportionality. Measures leading to the deprivation of nationality must serve a legitimate purpose that is consistent with international law and, in particular, the objectives of international human rights law. Such measures must be the least intrusive instrument of those that might achieve the desired result, and they must be proportional to the interest to be protected. In this respect, the notion of arbitrariness applies to all State action, legislative, administrative and judicial. The notion of arbitrariness could be interpreted to include not only acts that are against the law but, more broadly, elements of inappropriateness, injustice and lack of predictability also. ${ }^{78}$

Modern international law recognizes that dual nationality is inevitable and perhaps desirable. ${ }^{79}$ Today, international norms protect an individual's right to dual nationality. Although states retain clear discretion concerning dual nationality as a formal matter, pressure is growing on them to liberalize their practices.

In the general comments of the Human Rights Committee ("HRC") over the ICCPR, the expression 'arbitrary interference' could also extend to interference provided for by domestic law. ${ }^{80}$ In the HRC's view, the concept of 'arbitrariness' was introduced to guarantee that even formally lawful interference, in conformity with domestic law, should be in accordance with the provisions, aims and objectives of the ICCPR, and always be reasonable given particular circumstances. $^{81}$

Consequently, the concept of 'arbitrariness' also includes, beyond the 'unlawful,' elements of inappropriateness, injustice, illegitimacy or lack of predictability. ${ }^{82}$ This broad concept is necessary, for otherwise an interpretation of arbitrary deprivation as amounting only to illegal deprivation would make it far too easy for states to circumvent the aim of this prohibition. ${ }^{83}$ The HRC further indicated that the notion of arbitrariness applies to the action of all state organs. ${ }^{84}$

The 1997 European Convention is the first international legal instrument that recognizes and protects dual nationality. It no longer takes for granted that dual nationality necessarily works against states' interests. ${ }^{85}$ Using a rights approach, the convention obliges parties to permit dual/multiple nationality where it results from mixed-national parentage and international marriage. ${ }^{86}$ This latter protection not only promotes gender equality in nationality practice, but also can be further 
conceived as recognizing and validating the fact of dual nationality more generally. ${ }^{87}$

The 1997 European Convention also requires states not to make termination of original nationality a condition to naturalization when such termination is not possible or cannot be reasonably required. ${ }^{88}$ This new partial protection of dual nationality has shifted the discourse to one that accounts for the interests of individuals, not just of states. ${ }^{89}$ Although the convention is regional in scope, it is a watershed in global perceptions of the status of dual nationality ${ }^{90}$ as well as a new starting point for recognizing dual nationality. ${ }^{91}$

In 2009, the UN Human Rights Council ("UNHRC") issued its report on the right to a nationality, Human Rights and Arbitrary Deprivation of Nationality: Report of the Secretary-General. ${ }^{92}$ This Report uses the strongest wording prohibiting deprivation of nationality. It clearly states:

While the question of arbitrary deprivation of nationality does not comprise the loss of nationality voluntarily requested by the individual, it covers all other forms of loss of nationality, including those that arbitrarily preclude a person from obtaining or retaining a nationality, particularly on discriminatory grounds, as well as those that automatically deprive a person of a nationality by operation of the law, and those acts taken by administrative authorities that result in a person being arbitrarily deprived of a nationality. ${ }^{93}$

Judging from the UNHRC's statement above, Articles 5, 8-9 of the 1980 Nationality Act and Article 7 of the Implementing Rules all fall within the scope of arbitrary deprivation of nationality, so that their legitimacy might be challenged. In its 2013 Report, the UNHRC reaffirmed:

$\ldots$, measures that result in the loss or deprivation of nationality should be qualified as such and are subject to relevant international norms and standards. ${ }^{94}$ ... Even where loss or deprivation of nationality does not lead to statelessness, States must weigh the consequences of loss or deprivation of nationality against the interest that it is seeking to protect, and consider alternative measures that could be imposed. Under international law, loss or deprivation of nationality that does not serve a legitimate aim, or is not proportionate, is arbitrary and therefore prohibited. ${ }^{95}$ 
Most nationality law specialists take the view that there are no reasons which prevent a person from legitimately possessing more than one nationality. ${ }^{96}$ Indeed, if 'nationality' is perceived as primarily a legal bond between an individual and a state, it is unclear why one should not be able to maintain legal bonds with more than one state. Hailbronner points out that states are beginning to recognize the possibility of political membership in more than one state. ${ }^{97}$ Similarly, David Martin also deems that national allegiance can be genuine without being one-dimensional. The proper analogy for dual nationality, he says, is not bigamy, but rather the birth of a second child; a good parent extends complete love and devotion to the infant without diminishing the love and devotion felt toward the sibling. ${ }^{98}$

\section{Dual Nationality Practice in China: A History}

\section{A. Statutory Dual Nationality (1909-49)}

As China's first nationality law, the 1909 Nationality Act aimed at two points: (1) to define the status of nationality (jus sanguinis); and (2) to minimize the abuse of the lax naturalization laws of some foreign countries applied in their colonies near China. ${ }^{99}$ Originally, the 1909 Nationality Act was promulgated because the Dutch Government had attempted to naturalize Chinese residents of Java forcibly, claiming the allegiance of its subjects abroad. ${ }^{100}$ According to the 1909 Nationality Act, any Chinese who intended to acquire a foreign citizenship had to renounce beforehand his/her Chinese nationality upon approval. ${ }^{101}$ Also, those who failed to obtain such approval, though with foreign citizenship, would not be deemed as foreigners but Chinese. ${ }^{102}$ These provisions taken together (consentclause) amounted to a direct denial of expatriation, refusing to recognize that the acquisition of a new nationality ipso facto would extinguish a previous existing one, and necessarily gave rise to dual nationality. ${ }^{103}$

After the Republic of China was established on January 1, 1912, the 1909 Nationality Act was amended multiple times to reflect the republican form of government. ${ }^{104}$ The 1929 Nationality Act is still in force in Taiwan. The 1929 Nationality Act reflected the wishes of most overseas Chinese for dual nationality. ${ }^{105}$ Another concern of the Chinese legislature in enacting the 1929 Nationality Act 
was to preserve China's right to exercise diplomatic or consular protection over overseas Chinese. $^{106}$

The 1929 Nationality Act permitted a Chinese national to renounce his/her Chinese nationality upon the approval of the Ministry of the Interior (Article 11). The reason for adopting this rule was to prevent Chinese nationals from acquiring foreign nationality in order to avoid Chinese jurisdiction under the extraterritorial regime imposed by western powers on China before $1945 .{ }^{107}$

Again, there were some overseas Chinese who had lost their Chinese nationality through renunciation in order to acquire a foreign nationality in accordance with the law of the place where they resided but wished to recover their Chinese nationality. In order to meet their needs, the 1929 Nationality Act enabled them to recover it. ${ }^{108}$ So long as they were of good character, and possessed sufficient property or skills and abilities by which they could make an independent living, their Chinese nationality could be recovered at any time regardless of residence or domicile. ${ }^{109}$

\section{B. De Facto Dual Nationality in Hong Kong and Macau (1997-)}

In accordance with the PRC Constitution, basic laws of the Hong Kong SAR and the Macao SAR and their Annexes III, sole nationality should have been applied to Hong Kong and Macao citizens, as well. The Standing Committee of the PRC National People's Congress (hereinafter the Committee), however, vetoed its application. ${ }^{110}$ The Committee explained:

2. All Hong Kong Chinese compatriots are Chinese nationals, whether or not they are holders of the 'British Dependent Territories Citizens passport' or the 'British National (Overseas) passport'. With effect from 1 July 1997, Chinese nationals mentioned above may, for the purpose of travelling to other countries and territories, continue to use the valid travel documents issued by the Government of the United Kingdom. However, they shall not be entitled to British consular protection in the Hong Kong Special Administrative Region or other parts of the People's Republic of China on account of their holding the above-mentioned British travel documents.

3. According to the Nationality of the People's Republic of China, the British citizenship acquired by Chinese nationals in Hong Kong through the 'British Nationality Selection Scheme' will not be recognized. They are still Chinese 
nationals and will not be entitled to British consular protection in the Hong Kong Special Administrative Region and other parts of the People's Republic of China.

4. Chinese nationals of the Hong Kong Special Administrative Region with right of abode in foreign countries may, for the purpose of travelling to other countries and territories, use the relevant documents issued by the foreign governments.... However, they will not be entitled to consular protection in the Hong Kong Special Administrative Region and other parts of the People's Republic of China on account of their holding the above mentioned documents. ${ }^{111}$

Similar provisions are found in the Committee's interpretation of Macau citizens' dual nationality. Although, unlike Explanation 1996, it provides that Macanese of both Chinese and Portuguese descent may choose between Chinese and Portuguese nationality (Article 1, paragraph 2), Macanese are not deprived of their Chinese nationality upon acquisition of another one. ${ }^{112}$ So, Hong Kong and Macau citizens may retain their Chinese nationality while holding or acquiring foreign nationality. Actually, however, domestic nationality prevails. Those Hong Kong and Macau citizens who have foreign nationality are not treated as foreigners within Chinese territories, including Hong Kong and Macau, so that their foreign states may not claim against China a consular or diplomatic protection for them. That is why Chinese Foreign Minister Wang Yi averred that Lee Po was "first and foremost a Chinese" when he was present within Chinese territories. ${ }^{13}$

Thanks to the flexible approach, Hong Kong and Macau citizens continue to work in China, Hong Kong and Macau but send their families to western countries and set up businesses abroad. They may acquire multiple passports, second homes, overseas bank accounts and most importantly the flexibility to move around the globe.

\section{Dual Nationality in Mainland China (1980-)}

Legally speaking, Chinese citizens might conditionally have dual nationality if those provisions ${ }^{114}$ concerning dual nationality in the 1980 Nationality Act were interpreted literally without a view to the Act's object and purpose. Notwithstanding the narrow wording of those provisions, the Chinese government has repeatedly emphasized in public that the sole nationality principle "is consistently and explicitly proclaimed by our government," though somewhat rated as poetic 
license, ${ }^{115}$ and was well enforced before $2003 .^{116}$

In the end of 2003, China's Ministry of Public Security announced its Thirty Measures to Streamline Work Procedure. However, the phenomenon of dual nationality has gotten remarkable in China. Chinese returnees try hiding dual nationality status through loopholes in China's entry and exit administration. They have concealed their intention to emigrate and returned to mainland China via Hong Kong or Macau through a special entry-exit permit. The strategy enables those dual nationals to pass through Chinese immigration checkpoints without leaving any records of their foreign passports. Upon returning to China, their household registrations have been reinstated and they continue to access all rights such as the retirement fund, unemployment insurance, housing subsidies and others. ${ }^{117}$ In recent years, quite a few Chinese celebrities have been reported to have dual nationality. Even some government officials, representatives of both the National People's Congress and National Political Consultative Conference have dual nationality.

According to Chinese law, only Chinese nationals may be appointed as governmental employees. Article 12 of the 1980 Nationality Act clearly denies governmental employees and servicemen the right to expatriation, but says nothing about the legal consequences associated with their acquisition of foreign nationality. As a result, many Chinese returnees who have foreign residence or even foreign nationality have been appointed to important public positions. ${ }^{118}$ This situation has sparked public debate over dual nationality. How the government will deal with those loyalty conflicts remains to be seen.

In January 2016, the PRC Ministry of Public Security endorsed dual nationality while adding that no Chinese national may expatriate without Chinese government approval. ${ }^{119}$ This stance is absolutely incompatible with the sole nationality principle repeatedly averred by the Ministry of Foreign Affairs and the Overseas Chinese Affairs Office of the State Council. China's Ministry of Public Security made this statement shortly after Foreign Minister Wang Yi's response to his British counterpart Phillip Hammond on Lee Po's nationality. As Lee Po is a Hong Kong citizen (Chinese national), he may have dual nationality. His status of dual nationality has nothing to do with the sole nationality principle, in particular, under either interpretation or application of Article 9 of the 1980 Nationality Act, but concerns how to deal with the conflict arising from this question. 
Under Explanation 1996, ${ }^{120}$ the UK may not claim consular protection for Lee Po. For China's part, Lee Po is "first and foremost a Chinese [national]," not entitled to British consular protection within China's territories. Nonetheless, the interpretation and application of Article 9 of the 1980 Nationality Act has yet to be clarified. A Chinese legal writer argued that Article 9 would not apply to those Chinese nationals who have foreign nationality but reside in China (even including Hong Kong and Macau), and foreign Minister Wang Yi's response on Lee Po's case supported that reading. ${ }^{121}$ In his view, regardless of the 1980 Nationality Act's object and purpose, the overseas Chinese will not automatically lose their Chinese nationality unless they have settled abroad and been naturalized. ${ }^{122}$ A child born abroad to a Chinese national who has not settled abroad may be a dual national. ${ }^{123}$ No Chinese national may expatriate without Chinese government approval, either. ${ }^{124}$

However, neither Articles 5 nor 11 has ever been officially interpreted this way. In the early 1980s, the Chinese government discovered that some Chinese citizens who were residing in China had obtained foreign passports without renouncing their Chinese nationality. They asked for the same treatment as foreigners, thereby causing confusion "in our nationality work." ${ }^{125}$ There was no solution then, which implies that Article 9 would be not necessarily supposed to apply to only overseas Chinese nationals. Article 9 was somehow understood that way in a criminal case affirmed by the PRC Supreme Court at Yuan Mingang case (2000). ${ }^{126}$ As precedents are not a source of Chinese law, however, this interpretation has no general binding force.

Up till now, China has never promulgated any enforceable interpretation of those provisions. Interestingly, the official English wording of Articles 5 and 9, which have a slightly different meaning from their original Chinese text, clearly indicates that any Chinese national automatically loses his/her Chinese nationality upon naturalization or acquisition of a foreign nationality by birth wherever s/ he lives, i.e. foreign residence or domicile is not necessary for automatic loss of Chinese nationality.

What the sole nationality principle means in these circumstances is not clear from the letter of the law. China may require that persons concerned take steps formally to relinquish their foreign nationality. However, the final results must depend on getting the other state to agree to the proposed divestiture, ${ }^{127}$ which is 
not necessarily legitimate under contemporary international law. Instead, more legitimately and conveniently, China should officially recognize the status of dual nationality as it is, dealing with it by law rather than ignoring it.

\section{Conclusion}

China adopted the sole nationality principle in the 1950s, decades after accepting dual nationality. It was a particular product of the Cold War. However, it did not achieve its purpose to help the Chinese government win south-eastern Asian countries' trust, but created new problems of increased dual nationality cases out of control. Those problems, along with the right to a nationality, a human right respected by international law, support arguments supporting recognition of dual nationality. In no way shall the right to a nationality be interpreted as the right to 'only one' nationality but the right to "at least one" nationality.

Dual nationality was never generally prohibited by international law, and domestic and international laws prohibit arbitrary deprivation of nationality. China's 1980 Nationality Act provides for automatic loss of nationality, a form of arbitrary deprivation of nationality in the sense of the emerging international nationality norm. So, its legitimacy may still be challenged. In practice, dual nationality was recognized in China between 1909 and 1949 and is still applied to Hong Kong and Macao citizens. At present, China is not unable to deal with nationality conflicts. Also, international law has established a few principles of effectiveness, ${ }^{128}$ the most significant relationship, and genuine links. ${ }^{129}$ It would be in China's national interests to respect mainlanders' right to a nationality, and officially accept dual nationality instead of ignoring it. Bringing Chinese policy in line with international norms should help China to slow the nation's loss of its best and brightest to migration, help China retain capital and resources and promote social justice. 


\section{REFERENCES}

1. See The Law of Nationality: Research in International Law of the Harvard Law School, 23 Am. J. Int'L. L. 21 (1929) [hereinafter Harvard Research]. See also R. Donner, Nationality, in The Harvard Research in International Law: Contemporary Analysis and Appraisal 41-75 (J. Grant \& J. Barker eds., 2007), available at http://s1.downloadmienphi.net/file/ downloadfile4/206/1392182.pdf (last visited on Aug. 14, 2017).

2. Legally speaking, P. R. China consists of the Mainland, the Hong Kong SAR, the Macao SAR and Taiwan. Here in this article, however, the term 'China' refers to Mainland China unless otherwise specified. 'Chinese citizens' refers to Chinese Mainlanders, whereas 'Chinese nationals' refer to those who have Chinese nationality including citizens of Hong Kong and Macao.

3. Shuming Yang \& Hui Yin, Dual Citizenship and the Legal Practices: Debate on Revisions of Citizenship Law in China, 3 J. NANJING Normal U. [南京师范大学学报] (Social Science Edition) 30 (2006). See also Yongping Xiao \& Minglei Guo, Dual Citizenship in the Perspective of Globalization: On the Abuse and Countermeasures in China Citizenship, 59 Wuhan U. J. [武汉大学学报] (Philosophy \& Social Sciences Edition) 587 (2006). Again in 2016, dual nationality was re-proposed at the meeting of the 12th Chinese People's Political Consultative Conference, available at http://www.fx361.com/page/2016/0312/167297.shtml (last visited on July 23, 2017).

4. See China's Brain Drain Worst in the World Foreign Countries More Favorable [中国人才流 失居世界之首 专家称海外条件更优越], June 6, 2013, available at http://finance.people.com.cn/ n/2013/0606/c1004-21754321.html (last visited on Aug. 14, 2017). See also HuIYAo Wang \& Lv Miao ed., Blue Book of Global Talent: Annual Report on the Development of Chinese Students AbroAd (2013).

5. The Overseas Chinese Affairs Office of the State Council repeatedly turned down the request. See The most recent statement was made in December 2015, available at http://www. gqb.gov.cn/news/2015/1204/37312.shtml (last visited on July 23, 2017). See also PRC's Nationality Act (1980), art. 3.

6. Chinese law discriminates against overseas Chinese citizens, too. PRC migrants, though Chinese citizens, are required to have their household (hukou) registrations as well as identification cards deregistered. Consequently, they cannot enjoy the rights of Chinese citizens which are usually exercised or enforced through household registration and ID cards rather than passports. Thus, from the perspective of China's domestic law, they are only nominal Chinese citizens because their Chinese citizenship is assigned little legal value.

7. T. Molnár, The Prohibition of Arbitrary Deprivation of Nationality under International Law and EU Law: New Perspectives, 2014 Hungarian Y.B. InT'L L. \& Eur. L. 70 (2015), available at $\mathrm{http}: / /$ real.mtak.hu/29148/1/Deprivation\%20of\%20nationality_Molnar_HYIEL\% 202014.pdf (last visited on July 17, 2017). 
8. C. Dibble, The Chinese in Thailand against the Background of Chinese/Thai Relations (1962) (unpublished Ph.D. dissertation, University of Michigan), at 357; P. Hill, The Overseas Chinese in South-East Asia (1967) (M.A. thesis, McMaster University), at 33-8, , available at https://macsphere.mcmaster.ca/bitstream/11375/9751/1/fulltext.pdf (last visited on July 17, 2017); A. Barnett, China and Asia-Challenge to United States Policy 357 (1959).

9. Hill, supra note 8, at 37 (1967); Low Choo Chin, Debates over Liberalizing Dual Citizenship: Prospects and Limits in Taiwan and the People's Republic of China, 11 IJAPS 20 (2015).

10. W. Skinner, Report on Overseas Chinese: Cornell Data Paper 145 (1951).

11. In 1954, both Premier Chou En-Lai and Chairman Mao Tse-Tung stated that Overseas Chinese should not have dual nationality. See Suyin Han, Chou En-Lai and His Century [周 恩来与他的世纪] 323 (1996); Selected Works Of Mao Tse-Tung on Foreign Affairs 185 (1994).

12. This treaty, signed by Chinese Premier Chou En-Lai and Indonesian President Sukarno, came into force in 1960, but was renounced by Indonesia in 1966. See W. Bert, Chinese Relations with Burma and Indonesia, 15 Asian SuRv. 480 (June 1975).

13. See The Sino-Indonesia Treaty on Dual Nationality, 24 Far Eastern Surv. 75-6 (May 1955).

14. Joint Communique of the Government of the People's Republic of China and the Government of Federation of Malaysia (1974), art. 5.

15. Joint Communiqué of the Government of the People's Republic of China and the Government of the Republic of the Philippines (1975), $\uparrow 9$.

16. Joint Communiqué of the Government of the People's Republic of China and the Government of Thailand Kingdom (1975), art. VIII.

17. See the official English text of the 1980 Nationality Act, available at http://www.npc.gov. cn/englishnpc/Law/2007-12/13/content_1384056.htm (last visited on May 4, 2017).

18. While drafting the 1980 Nationality Law, the PRC believed that it would be better for the long-term interests of overseas Chinese to stipulate the non-recognition of dual nationality. See Zhen Peng, Report on the Work of N.P.C. Standing Committee, 23 (39) Beijng Rev. 32 (Sept. 29, 1980), available at https:/www.marxists.org/subject/china/peking-review/1980/ PR1980-39.pdf (last visited on July 23, 2017).

19. Yu Sheng, China's Nationality Act and the Principles of International Law, Chinese Y.B. INT'L L. 205-15 (1982).

20. Keju Wang, The Basic Principles of China's Nationality Act, Chinese Y.B. Int'L L. 216-38 (1982).

21. V. Pechota, Review: Selected Articles from Chinese Yearbook of International Law by Chinese Society of International Law, 79 AM. J. INT'L L. 853 (1985), available at http:www. jstor.org/stable/2201949 (last visited on July 23, 2017).

22. Rules for Implementing Entry \& Exit Act of the People's Republic of China (hereinafter Implementing Rules), art. 7; Thirty Measures to Streamline Procedure (hereinafter Thirty 
Measures), art. 6.

23. See Foreign Minister Chen Yi's Letter to Indonesian Foreign Minister Subandrio, 2 (50) PekING Rev. 6-7 (Dec. 15, 1959), available at https://www.marxists.org/subject/china/pekingreview/1959/PR1959-50.pdf (last visited on July 17, 2016).

24. Hill, supra note 8, at 86.

25. P. Spiro, Dual Citizenship as Human Right, Temple University Beasley School of Law Legal Studies Research Paper Series (No. 2009-41) 6 (2009), available at http://ssrn.com/ abstract=1489005 (last visited on July 3, 2017).

26. China's first mass migration lasted from the 16th century till the middle of the 19th centuries, and its second, from the late 19th century till the first half of the 20th century. The third began in the 1970s, peaked in the 1990s and goes on till now. See Guotu Zhuang, New Characteristics of Chinese Migrates in Globalization Era [全球化时代中国海外移民的新特 点], 8 PeOPLE's TRIBUne [人民论坛] • FrontiERs [学术前沿] 88 (Apr. 2015).

27. It is very common for the so-called successful Chinese, including governmental officials, business elites and university professors, to have foreign passports and raise their families abroad while working in China. They possibly hold both Chinese and foreign passports while enjoying foreigners' privileges in China. They are called 'bogus foreigners,' different from foreign citizens of Chinese descent.

28. E.g., foreign-invested companies enjoy preferential treatment on taxes and fees including reduction or exemption of land transfer fees, income tax, sales tax, etc. See Zhenghua Tao, Dual Nationality Does No Good but Harms to China [中国放开双重国籍, 有弊无利], 10 GreEN Leaf 53-5 (2009), available at https://wenku.baidu.com/view/74fb032e915f804d 2b16c145.html (last visited on Aug. 14, 2017).

29. G. Comparato, Nationalism and Private Law in Europe (2012), available at hittps://pure. uva.nl/ws/files/1514670/111630_05.pdf (last visited on July 14, 2017).

30. Siag \& Vecchi v. Egypt, ICSID Case No. ARB/05/15 (Apr. 11, 2007), available at https:// www.italaw.com/documents/WaguihElieGeorgeSiag-AwardandDissentingOpinion_001.pdf (last visited on July 23, 2017).

31. Id. ๆๆ 196-200.

32. International law refers to nationality, but only as a matter of order management. See P. Spiro, A New International Law of Citizenship, 105 Am. J. InT'L L. 698 (2011).

33. PRC Law on Application of Laws to Foreign-Related Civil Relations (2011), art. 20.

34. The 2003 Rules, arts. 6-8.

35. Tao, supra note 28.

36. Jianfeng Zhang, China to streamline 'green card' application for foreigners, XINHUANET, Sept. 15, 2015, available at http://english.cntv.cn/2015/09/15/ARTI1442311047333435. shtml (last visited on Aug. 14, 2017).

37. See China to ease green card rules to draw foreign talent, Strait Times, Jan. 13, 2016, available at $\mathrm{http}: / / \mathrm{www}$. straitstimes.com/asia/east-asia/china-to-ease-green-card-rules-to- 
draw-foreign-talent (last visited on July 29, 2017).

38. O. Vonk, Dual Nationality in the European Union: A Study on Changing Norms in Public and Private International Law and in the Municipal Laws of Four European States 50 (2012).

39. See To Whom Chinese Green Cards Are Granted [中国绿卡发给谁], 20 OrIEnTAL OutLooK [瞭 望东方周刊] (2011).

40. Xi Cheng Dual Nationality: Little Difficult in Law But Much Trouble in Politics [双重国籍: 法律好办, 政治为难], SOUTHERN WeEKLY [南方周末], Mar. 31, 2011.

41. Vonk, supra note 38, at 12 (n. 11). See also G. Casper, The Concept of National Citizenship in the Contemporary World: Identity or Volition? 4-5 (2008), available at https://gcasper. stanford.edu/pdf/National-Citizenship-Identity.pdf; D. Martin, Dual Citizenship: Reflections on Theodore Roosevelt's 'Self-Evident Absurdity,' Virginia Public Law \& Legal Theory Research Paper (No. 2014-58) 2-3 (2014), available at http://ssrn.com/abstract=2500463 (all last visited on July 23, 2017).

42. Martin, id.

43. The 1804 Civil Code of France, art. 23.

44. P. Spiro, Mandated Membership, Diluted Identity: Citizenship, Globalization and International Law, in People out of Place 94-5 (A. Brysk \& G. Shafir eds., 2004).

45. Id.

46. Casper, supra note 41 , at 3.

47. P. Weis, Nationality and Statelessness in International Law 133 (2d. 1979).

48. Vonk, supra note 38, at 145 (n. 170).

49. UDHR art. 15.

50. ICCPR, pmbl., arts. 1, \4 \& 24, ๆ 3.

51. The American Convention on Human Rights 1969, art. 20.

52. The Paris Minimum Standards of Human Rights Norms in a State of Emergency, art. 14. See R. Lillich, The Paris Minimum Standards of Human Rights Norms in a State of Emergency, 79 Aм. J. INT'L L. 1081 (1985), available at http://www.uio.no/studier/emner/ jus/humanrights/HUMR5503/h09/undervisningsmateriale/ParisMinimumStandards.pdf (last visited on July 15, 2017).

53. Arab Charter on Human Rights 1994, art. 29, $\uparrow 1$ \& 3, available at https//www. humanrights.ch/upload/pdf/091029_Arab_Charter_on Human_Rights_2004.pdf (last visited on July 15, 2017).

54. European Convention on Nationality 1997, art. 4, $\mathbf{9}$ a \& c, available at https://rm.coe. int/168007f2c8 (last visited on July 15, 2017).

55. ASEAN Human Rights Declaration 2012, general princ., \ 18, available at http://aichr.org/ documents (last visited on July 15, 2017).

56. Proposed Amendments to the Naturalization Provisions of the Constitution of Costa Rica, Advisory Opinion OC-4/84, Inter-Am. Ct. H.R, 『 33, (Jan. 19, 1984), available at http:// 
www.worldcourts.com/iacthr/eng/decisions/1984.01.19_Proposed_Amendments.pdf (last visited on July 15, 2017).

57. Draft Articles on Nationality of Natural Persons in relations to the Succession of States with Commentaries [1999] 24 Y.B Int'1 L. Comm'n Vol. II, Part 2, available at http://www. refworld.org/pdfid/4512b6dd4.pdf (last visited on Aug. 5, 2017).

58. Id.

59. Spiro, supra note 32, at 694.

60. Haopei Li, Comparative Analysis on Nationality [国籍问题的比较研究] 5 (1979).

61. Spiro, supra note 32, at 708 (n. 87).

62. Expatriation was written into the 1929 Harvard Draft Convention on Nationality. See F. Deák, Review on Research in International Law, Draft Conventions on Nationality, Responsibility of States, Territorial Waters, 30 CoL. L. Rev. 142-4 (1930).

63. R. Jennings \& A. Watts, Oppenheim's International Law 852 (9th ed. 2008).

64. Nationality Decrees Issued in Tunis and Morocco on Nov. 8, 1921, Advisory Opinion, 1923 P.C.I.J. (ser. B) No. 4, at 24 (Feb. 7), available at http://www.worldcourts.com/pcij/eng/ decisions/1923.02.07_morocco.htm (last visited on July 17, 2017).

65. Spiro, supra note 32, at 708.

66. Haiyuan Huang, Right to A Nationality in the Era of Globalization [全球化视野下的国籍 权研究] (2012), at 28-9, (unpublished Ph.D. Dissertation, The Party School of the Central Committee of the Chinese Communist Party) (2012).

67. In that period of time, forced expatriation was provided in quite a few bilateral agreements including Sino-foreign nationality treaties, and the Convention on the Reduction of Cases of Multiple Nationality and Obligations in Cases of Multiple Nationality (hereinafter 1963 European Convention). No evidence suggests that forced expatriation might have come into being as an international norm. See Spiro, supra note 32, at 740.

68. Spiro, id.

69. Afroyim v. Rusk, 387 U.S. 253, 87 S. Ct. 1660, 18 L. Ed. 2d 757, 1967 U. S. Lexis 2844, at 264, available at https://www.courtlistener.com/opinion/107464/afroyim-v-rusk (last visited July 16, 2017).

70. Vance v. Terrazas, 444 U.S. 253, 100 S. Ct. 540, 62 L. Ed. 2d. 461, 1980 U.S. Lexis 63, at 541, available at https://www.courtlistener.com/opinion/110168/vance-v-terrazas (last visited on July 16, 2017).

71. The 1963 European Convention (as amended by Protocol 1993-2-2), art. 1, ๆף 5-7, available at http://www.jus.uio.no/english/services/library/treaties/02/2-07/multiple-nationality.xml (last visited on July 23, 2017).

72. The 1980 Nationality Law, art. 9, available at http://www.npc.gov.cn/englishnpc/Law/200712/13/content_1384056.htm (last visited on Aug. 14, 2014).

73. UN Human Rights Council, Human Rights and Arbitrary Deprivation of Nationality: Report

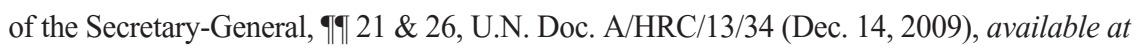


http://www.refworld.org/docid/4b83a9cb2.html (last visited on July 16, 2017).

74. Molnár, supra note 7, at 71 (n. 24). Some authors are not convinced about its customary international rule. See Spiro, supra note 32, at 707.

75. Nottebohm (Liech. v. Guat.), Judgement, 1955 I.C.J. Rep. 4 (Apr. 6), available at http:// www.worldcourts.com/icj/eng/decisions/1955.04.06_nottebohm.htm (last visited on July 16, 2017).

76. Supra note 56.

77. UN Human Rights Council, Human rights and arbitrary deprivation of nationality: Report of the Secretary-General, 97 , U.N. Doc. A/HRC/25/28 (Dec. 19, 2013), available at http:// www.refworld.org/docid/52f8d19a4.html (last visited on July 16, 2017).

78. UN Human Rights Council, supra note 73, $\mid 25$.

79. P. Spiro, Beyond Citizenship: American Identity after Globalization 59-60 (2008). See also C. Forcese, Shelter from the Storm: Rethinking Diplomatic Protection of Dual Nationals in Modern International Law, 37 Geo. Wash. InT'L L. Rev. 490-1 (2005), available at https://litigation-essentials.lexisnexis.com/webcd/app?action=DocumentDispla y\&crawlid $=1 \&$ doctype $=$ cite $\&$ docid $=37+$ Geo. + Wash. + Int $\% 271+$ L. + Rev. $+469 \&$ srctype $=$ smi $\&$ srcid=3B15\&key=e9cce6c24d0c5e7fcadf29d628925ca2 (last visited on Aug. 6, 2017).

80. UN Human Rights Committee, CCPR General Comment No. 16: Article 17 (Right to Privacy), The Right to Respect of Privacy, Family, Home and Correspondence, and Protection of Honor and Reputation (April 8, 1988), \4, available at http://www.refworld. org/docid/453883f922.html. See also UN Human Rights Committee, CCRP Comment No. 27: Article 12 Freedom of Movement, U.N. Doc. CCPR/C/21/Rev. 1/Add. 9 (Nov. 2, 1999), 921, available at http://www.refworld.org/docid/45139c394.html (all last visited on July 16, 2017).

81. Molnár, supra note 7, at 77 (n. 55).

82. UN Human Rights Committee, A. v. Australia, Communication No. 560/1993, U.N. Doc. CCPR/59/D/560/1993 (Apr. 30, 1997), available at http://hrlibrary.umn.edu/undocs/html/ vws560.html (last visited on July 16, 2017).

83. S. Mantu, Deprivation of Citizenship from the Perspective of International and European Legal Standards, ENACT Consortium, FP7-SSH-2007-1-217504-ENACT/D4.2, at 10.

84. UN Human Right Council, supra note 73, 9 ฯ 49-50.

85. The 1997 European Convention, pmbl., available at http://www.refworld.org/ pdfid/3ae6b36618.pdf (last visited on May 3, 2017).

86. Id. art. 14 .

87. K. Hailbronner, Nationality in Public International Law and European Law, in ACQUisition and Loss of Nationality: Politics and Trends in 15 European Countries 45-6 (R. Bauböck et al. eds., 2006).

88. The 1997 European Convention, art. 16.

89. Id. pmbl. It provides: “... Recognizing that, in matters concerning nationality, account 
should be taken both of the legitimate interests of States and those of individuals; ..." [Emphasis added]

90. Spiro, supra note 32, at 734 (n. 284).

91. Id. Between the 1990s and the 2000s, many countries shifted to dual nationality. According to the latest statistics, the proportion of states automatically terminating citizenship upon naturalization in another country dropped from 55 percent in 1960 to 30 percent in 2013. Nineteen out of the top 20 states of origin for immigrants to the US either accept dual citizenship or do nothing to police against it. See P. Spiro, A Home at Two Countries: The Past And Future of Dual Nationality 70 (2016).

92. UN Human Rights Council, supra note 73.

93. Id. $\mid 23$.

94. Human Rights Council, supra note 77, 93.

95. Id. 40. See also R. de Groot, Survey on Rules on Loss of Nationality in International Treaties and Case Law, CEPS Paper in Liberty and Security in Europe No. 57, at 20-2 (notes 79-89) (2013) [6. Arbitrary deprivation], available at https://www.ceps.eu/system/files/ No\%2057\%20Loss\%20of\%20Nationality\%20ILEC.pdf (last visited on July 23, 2017).

96. Vonk, supra note 38, at 62.

97. Id.

98. Martin, supra note 41, at 14.

99. Chutung Tsai, The Chinese Nationality Law, 1909, 4 Aм. J. INT’L L. 404 (1910).

100. Id. 407. See also Shao Dan (2009) Chinese by Definition; Nationality Law, Jus Sanguinis, and State Succession, 1909-1980, 35 (1) Twentieth-Century China 4-28 (2009).

101. The 1909 Nationality Act, art. X. See Jinjun Ding (ed.), Nationality Regulation of Qing Dynasty, 3 Historical Archives (1988).

102. The 1909 Nationality Act, art. XVIII. See Ding id.

103. Tsai, supra note 99 , at 408.

104. Hungdah Chiu, Nationality and International Law in Chinese Perspective, 3 OcCASIONAL Papers/Reprint Series in Contemporary Asian Studies 8 (n. 28) (Hungdah Chiu et. al. eds., 1990), reprinted from Ko Swan SiK, ed., Nationality and International LaW in Asian Perspective (1990), available at http://digitalcommons.law.umaryland.edu/cgi/ viewcontent.cgi?article $=1097 \&$ context $=$ mscas $\&$ sei-redir $=1 \&$ referer $=\mathrm{http} \% 3 \mathrm{~A} \% 2 \mathrm{~F} \% 2 \mathrm{Fcn}$. bing.com $\% 2$ Fsearch $\% 3 \mathrm{Fq} \% 3 \mathrm{DHungdah} \% 2 \mathrm{BChiu} \% 252 \mathrm{C} \% 2 \mathrm{BNationality} \% 2 \mathrm{Band} \% 2$ BInternational\%2BLaw\%2Bin\%2BChinese $\% 2 \mathrm{BPerspective} \% 252 \mathrm{C} \% 26 \mathrm{go} \% 3 \mathrm{D} \% 25 \mathrm{E}$ $6 \% 2590 \% 259 \mathrm{C} \% 25 \mathrm{E} 7 \% 25 \mathrm{~B} 4 \% 25 \mathrm{~A} 2 \% 26 \mathrm{qs} \% 3 \mathrm{Dbs} \% 26$ form $\% 3 \mathrm{DQBRE}$ search $=\%$ 22Hungdah\%20Chiu\%2C\%20Nationality\%20International\%20Law\%20Chinese $\% 20$ Perspective \%2C\%22 (last visited on July 16, 2017).

105. Guixiang Ren, The Second Patriotic Tide of Overseas Chinese [华侨第二次爱国高潮] 136 (1989). See also Boji Liu, A History of the Chinese in the United States of America [美 国华侨史] 682 (1981); Shaochuan Lin, Cheng Jiageng and Overseas Chinese Mechanics 
[陈嘉庚与南侨机工] 400-1 (1994); Hua Liu, Overseas Chinese Nationality and China's NATIONALITY LAW [华侨国籍问题与中国国籍立法] 144-50 (2004); EdITORIAL BoARD OF THE Revolutionary History of Overseas Chinese, The Revolutionary History of Overseas Chinese [华侨革命史] 705-6 (1981); Jinzhi Lin, Overseas Chinese and China’s Revolution AND CONSTRUCTION [华人华侨与祖国革命和建设] 283-4 (1993).

106. During the 1933 Mexican anti-Chinese movement, e.g., Chinese businessmen were forced to shut down their firms; thousands of Chinese there lost their jobs and were illegally deported. The Chinese minister in Mexico protested that the Mexican government should be wholly responsible for the riot and China reserved the right to compensation. See Dianzeng Xue, Protection of Overseas Chinese [保护侨民论] 98, 101, 119 \& 121 (1937).

107. Chiu, supra note 104, at10 (n. 39).

108. Id.

109. The 1929 Nationality Act, art. 16, \1, available at http://www.yoshabunko.com/nationality/ ROC_nationality_law.htmlThe 1929 Nationality Act (last visited on July 23, 2017).

110. The Committee never specified, at least in public, the particular or peculiar historical background and reality of Hong Kong. However, the Sino-British Joint Declaration and its annexes showed that Hong Kong citizens enjoyed and would keep enjoying more rights and freedoms, including right of travel and movement of course, than Chinese mainlanders. See Joint Declaration of the Government of the United Kingdom of Great Britain and Northern Ireland and the Government of the People's Republic of China on the Question of Hong Kong: Elaboration by the Government of the PRC of Its Basic Policies Regarding Hong Kong, Annex I, available at http://www.cmab.gov.hk/en/issues/jd3b. $\mathrm{htm}$. See also Joint Declaration of the Government of the People's Republic of China and the Government of the Republic of Portugal on the Question of Macao: Elaboration by the Government of the PR C of Its Basic Policies Regarding Macao, art. V, Annex I, $\mathbb{1}$, available at http://bo.io.gov.mo/bo/i/88/23/dc/en (all last visited on May 3, 2017).

111. See Explanation of Some Questions by the Standing Committee of the National People's Congress concerning Implementation of the Nationality Law of the People's Republic of China in the Hong Kong Special Administrative Region (hereinafter Explanation 1996), available at https://www.gov.hk/en/residents/immigration/chinese/law.htm (last visited on July 16, 2017).

112. See Interpretation by the Standing Committee of the National People's Congress on Some Questions concerning Implementation of the Nationality Law of the People's Republic of China in the Macao Special Administrative Region of the PRC, available at http://www. asianlii.org/cn/legis/cen/laws/ibtscotnpcosqciotnlitmsar1708 (last visited on July 16, 2017).

113. Frank Ching, Chinese worldwide all PRC nationals?, СніnA Posт, May 4, 2016, available at http://www.chinapost.com.tw/commentary/china-post/frank-ching/2016/05/04/465087/ Chinese-worldwide.htm (last visited on June 17, 2016).

114. The 1980 Nationality Law, arts. 5, 9, $11 \& 14$. 
115. G. Gingsburgs, The 1980 Nationality Law of the People's Republic of China, 30 Ам. J. Comp. L. 465 (1982).

116. Before the end of 2003, a Chinese national who was going to stay abroad for more than one year had to have his/her household registration deregistered so as to obtain his/her passport. Nowadays, not all Chinese citizens are required to have their household registration deregistered before going abroad, which actually gives rise to dual nationality.

117. E. Ho Lynn-Ee, Caught between Two Worlds: Mainland Chinese Return Migration, Hukou Considerations and the Citizenship Dilemma, 15 (6-7) Citizenship Stud. 653 (2011).

118. See The Great Green Card Debate in Greater China, ChinaStakes, June 23, 2008, available at http://chinastakes.com/2008/6/the-great-green-card-debate--in--greater-china.html (last visited on July 17, 2017).

119. China's Ministry of Public Security: Chinese-Born Americans Are Still Chinese Nationals No Matter How Long They Have Been American Nationals [大陆公安部 美籍华人入籍35 年仍属中国公民], available at http://boxun.com/news/gb/china/2016/01/201601140019. shtml\#.V2P0WdygWJk (last visited on June 17, 2017).

120. Explanation 1996, I 3, available at https://www.gov.hk/en/residents/immigration/chinese/ law.htm (last visited on July 16, 2017).

121. Three Gross Misunderstandings of China's Nationality Law - China's Nationality Law Impliedly Recognizes Dual Nationality [三个对中国国籍法的重大误解 中国国籍法实际已默 认双重国籍], available at http://blog.sciencenet.cn/blog-5681-407904.html (last visited on June 17, 2017).

122. The 1980 Nationality Law, art. 9. [Emphasis added]

123. Id. art. 5.

124. Id. art. 11.

125. Qiuxiang Gong, On the Nationality Law, 23 (45) BeiJng Rev. 25 (1980).

126. The accused Yuan held both Chinese and Japanese nationality, alleging that, under Article 9 of the 1980 Nationality Law, he automatically lost his Chinese nationality, and used his Japanese passport while returning. But the court ruled against him, stating that Article 9 was not applicable because he had never settled abroad. Furthermore, the court asserted that it would wrong to assume any Chinese national who had a foreign nationality to be a foreigner. See China's Supreme Court, Vol. 4 References for Criminal Justice [刑事审判参 考] 34-8 (2000).

127. Like Sino-American treaties, Treaty of Tientsin (1858) and Burlingame-Seward Treaty (1868) prohibited Chinese permanent emigration into and naturalization in the US, available at https://academic.udayton.edu/race/02rights/immigr05.htm (last visited on June 18, 2017).

128. Italian-US Conciliation Commission, Mergé Case-Decision No. 55, June 10, 1955, available at http://www.uniset.ca/naty/merge.pdf (last visited on Aug. 14, 2017). The Commission founded the principle of effectiveness, meaning that dual nationals ought to be taken as the 
national of the state where its nationality is effective.

129. Nottebohm Case, supra note 75. 
